\title{
Regulation of Spine Formation by ErbB4 in PV-Positive Interneurons
}

\author{
Dong-Min Yin, ${ }^{1}$ Xiang-Dong Sun,,${ }^{1,2}$ Jonathan C. Bean, ${ }^{1}$ Thiri W. Lin, ${ }^{1}$ Anupama Sathyamurthy, ${ }^{1}$ Wen-Cheng Xiong, ${ }^{1,3,4}$ \\ Tian-Ming Gao, ${ }^{2}$ Yong-Jun Chen, ${ }^{1,2}$ and Lin Mei ${ }^{1,2,3,4}$ \\ ${ }^{1}$ Institute of Molecular Medicine and Genetics, Medical College of Georgia, Georgia Regents University, Augusta, Georgia 30912, ${ }^{2}$ Department of \\ Neurobiology, Southern Medical University, Guangzhou, Guangdong, China, ${ }^{3}$ Department of Neurology, Medical College of Georgia, Georgia Regents \\ University, Augusta, Georgia 30912, and ${ }^{4}$ Charlie Norwood Veterans Administration Medical Center, Augusta, Georgia 30912
}

The trophic factor neuregulin 1 (Nrg1) and its receptor ErbB4 are schizophrenia candidate genes. NRG1-ErbB4 signaling was thought to regulate spine formation and function in a cell-autonomous manner. Yet, recent studies indicate that ErbB4 expression is largely restricted to GABAergic interneurons and is very low or absent in pyramidal cells. Here, we generated and characterized cell type-specific ErbB4 mutant and transgenic mice. Spine density and the number of excitatory synapses were unaltered by neither deletion nor overexpression of ErbB4 in pyramidal neurons. However, spine density and excitatory synapse number were reduced in PV-ErbB4 ${ }^{-1-}$ mice where ErbB4 was selectively ablated in parvalbumin-positive GABAergic interneurons. Concurrently, basal glutamate transmission was impaired in PV-ErbB4 ${ }^{-I-}$ mice, but not in mice where ErbB4 was deleted or overexpressed in pyramidal neurons. Our results demonstrate a role of ErbB4 in PV-positive interneurons for spine formation in excitatory neurons.

Key words: neuregulin; ErbB4; GABAergic; glutamatergic; spine; schizophrenia

\section{Introduction}

Schizophrenia is a neural developmental disorder characterized by impaired perception, cognition, and motivation (Weinberger, 1987; Lewis and Levitt, 2002). These impairments may result from altered assembly and function of excitatory and inhibitory pathways (Lewis and Sweet, 2009; Yin et al., 2012). Excitatory synapses onto pyramidal neurons are formed by glutamatergic axon terminals onto spines, protrusions from dendritic shafts of pyramidal neurons (Gray, 1959; Harris and Kater, 1994). Consistent with synaptic dysfunction in schizophrenia, recent studies suggest spines as important substrates in pathogenesis of this disorder (Penzes et al., 2011; Glausier and Lewis, 2013).

Neuregulin 1 (NRG1) is a large family of EGF-domaincontaining trophic factors that act by activating ErbB receptor tyrosine kinases (Mei and Xiong, 2008). Both Nrg1 and ErbB4, the only ErbB that can function as homodimer, have been identified as schizophrenia susceptibility genes (Stefansson et al.,

Received May 16, 2013; revised Oct. 30, 2013; accepted Nov. 2, 2013.

Author contributions: D.-M.Y., W.-C.X., T.-M.G., Y.-J.C., and L.M. designed research; D.-M.Y., X.-D.S., J.C.B., T.W.L., A.S., and Y.-J.C. performed research; D.-M.Y. and Y.-J.C. analyzed data; D.-M.Y., W.-C.X., Y.-J.C., and L.M. wrote the paper.

This work was supported in part by the National Institute of Mental Health, National Institutes of Health. L.M. is a National Alliance for Research on Schizophrenia and Depression Distinguished Investigator. D.-M.Y. is a National Alliance for Research on Schizophrenia and Depression Young Investigator. Y.-J.C. receives a postdoctoral fellowship from American Heart Association. We thank Dr. Joe Tsien for pMM400 plasmid and Camk2 $\alpha$-Cre mice, Dr. Cary Lai for anti-ErbB4 antibody (0618) and floxed ErbB4 mice, and Dr. Silver Arber for PV-Cre mice.

The authors declare no competing financial interests.

Correspondence should be addressed to either Dr. Yong-Jun Chen or Dr. Lin Mei, Institute of Molecular Medicine and Genetics, Medical College of Georgia, Georgia Regents University, 2500 Walton Way, Augusta, GA 30904, E-mail: ychen@gru.edu or Imei@gru.edu.

DOI:10.1523/JNEUROSCI.2090-13.2013

Copyright $\odot 2013$ the authors $\quad 0270-6474 / 13 / 3319295-09 \$ 15.00 / 0$
2002; Yang et al., 2003; Silberberg et al., 2006; Sullivan et al., 2008; Walsh et al., 2008; Shi et al., 2009). Recent studies have revealed that NRG1 and ErbB4 play important roles in neural development as well as synaptic plasticity (Huang et al., 2000; Flames et al., 2004; Woo et al., 2007; Pitcher et al., 2008; Chen et al., 2010; Fazzari et al., 2010; Wen et al., 2010; Ting et al., 2011; Del Pino et al., 2013).

NRG1-ErbB4 signaling has been implicated in spine formation or maturation. Fewer spines were observed in hGFAP:: Cre;ErbB4f/f mice where ErbB4 was ablated in all neural cells (Barros et al., 2009). However, the underlying mechanisms remain unclear. Treatment with soluble NRG1 increased the number of spines in cultured hippocampal neurons (Barros et al., 2009) but had little effect on the density and size of PSD-95 puncta in cortical pyramidal neurons (Ting et al., 2011). Knockdown of ErbB4 reduced spine density and size in organotypical hippocampal slices (Li et al., 2007). However, the cell-autonomous function of ErbB4 in spine formation deserves a revisit because ErbB4 ablation in pyramidal neurons by viral infection did not alter the density of dendritic spines (Fazzari et al., 2010). Moreover, recent studies indicate that ErbB4 expression is largely restricted to GABAergic interneurons and is very low or absent in pyramidal cells (Vullhorst et al., 2009; Fazzari et al., 2010).

Here we addressed these discrepancies by in vivo genetic studies. We found that neither deletion nor overexpression of ErbB4 in pyramidal neurons altered spine density and number of excitatory synapses in vivo. However, the spine density and number of excitatory synapses in pyramidal neurons were reduced in PV-ErbB $4^{-1-}$ mice where ErbB4 was selectively deleted in PVpositive GABAergic interneurons. These results demonstrate a 
A

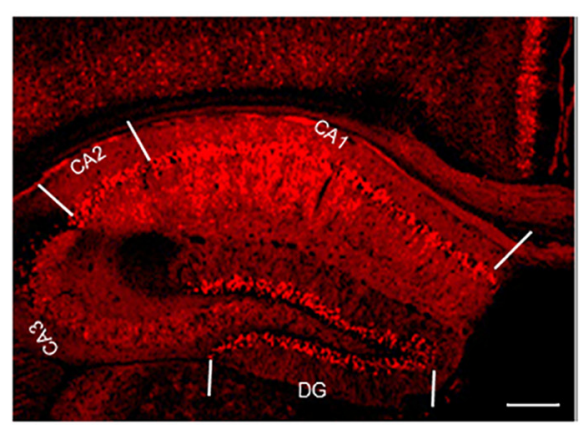

D

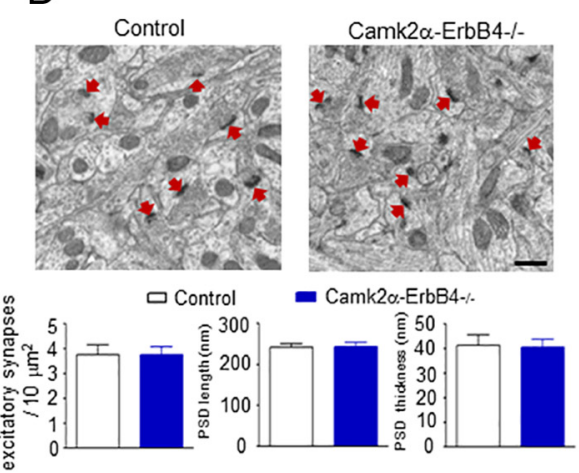

E
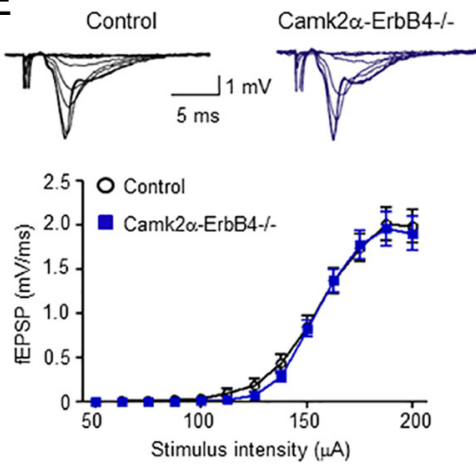

C

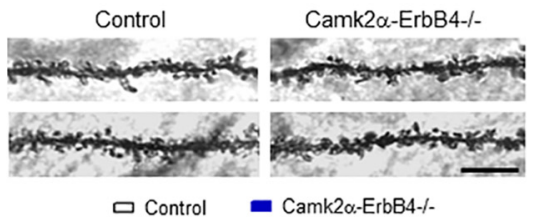

$\square$ Control $=$ Camk2o-ErbB4\%
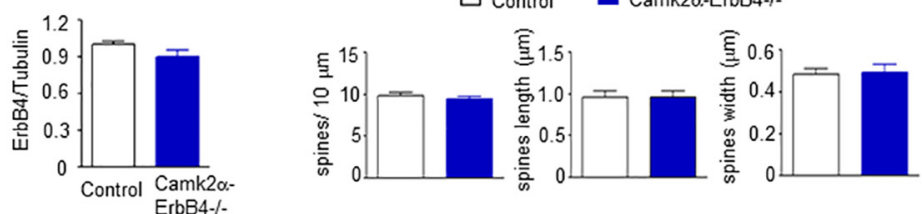

$\mathrm{F}$
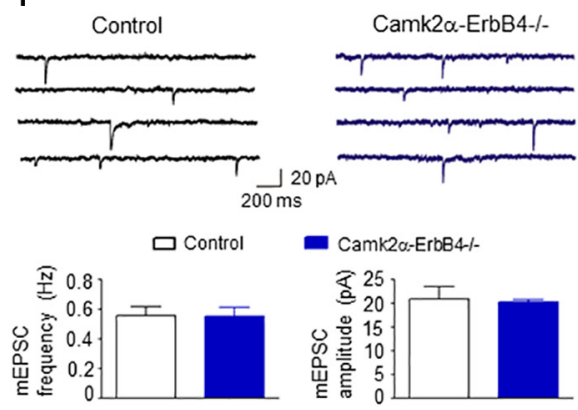

Figure 1. Deletion of ErbB4 in pyramidal neurons has no effect on spine formation. $\boldsymbol{A}$, Cre activity was expressed in forebrain pyramidal neurons in Camk2 $\alpha:$ :Cre mice. Camk2 $\alpha:$ ::Cre mice were crossed with Rosa-tdTomato mice. Shown were a hippocampal slice of resulting Camk2 $\alpha:$ :Cre;Rosa-tdTomato mice. Scale bar, $200 \mu \mathrm{m}$. B, Similar ErbB4 levels in the hippocampus between Camk2 $\alpha$-ErbB4 ${ }^{-1-}$ mice and control littermates. Top, Representative blots of ErbB4 and tubulin. Bottom, Quantification data. Expression levels of ErbB4 were normalized by tubulin. C, The density, length, and width of spines were indistinguishable between control and Camk2 $\alpha-E r b B 4^{-/-}$mice. Top, Representative images. Bottom, Quantitative data. $n=33$ neurons from 3 mice per group. Scale bar, $10 \mu \mathrm{m}$. D. Comparable numbers of excitatory synapses, PSD length, and PSD thickness in the CA1 region between control and Camk2 $\alpha$-ErbB4 ${ }^{-1-}$ mice. Top, Representative EM images. Bottom, Quantitative data. $n=108$ images from 3 mice per group. Arrows indicate PSD. Scale bar, $0.5 \mu \mathrm{m}$. $\boldsymbol{E}$, Similar l/0 curves of fEPSP at SC-CA1 synapses between control and Camk2 $\alpha$ ErbB4 ${ }^{-1-}$ mice. $n=12$ slices from 4 or 5 mice per group. Top, Representative traces of fEPSPs. Bottom, $I / 0$ curves. $F$, No difference in mEPSC frequency and amplitude between control and Camk2 $\alpha$-ErbB4 ${ }^{-I-}$ mice. Top, Representative traces. Bottom, Quantification data. $n=9$ cells from 3 mice per group.

role of ErbB4 from PV-positive interneurons in regulating spine formation.

\section{Materials and Methods}

Generation of mice. Camk $2 \alpha-E r b B 4^{-1-}$ and PV-ErbB4 $4^{-1-}$ mice were generated as described previously (Chen et al., 2010). Rosa-tdTomato reporter mice were from The Jackson Laboratory (stock number 007909) (Madisen et al., 2010). To create transgenic mice where ErbB4 is overexpressed in pyramidal neurons, full-length human ErbB4 was cloned into the EcoR V site of the pMM400 plasmid (kindly provided by Dr. Joe Tsien, Georgia Regents University). A NotI fragment containing the transgene was isolated and used for transgenic mouse production. Transgenic C57BL/6-CBA(J) F2 founders, TRE-ErbB4 mice, were backcrossed with $\mathrm{C} 57 \mathrm{BL} / 6 \mathrm{~N}$ mice for 6 generations before crossing with Camk $2 \alpha::$ TTA mice (The Jackson Laboratory, stock number 007004) to generate bitransgenic Camk2 $\alpha:$ tTA;TRE-ErbB4 mice (ctoErbB4 for Camk $2 \alpha$ promoter driven tet-off ErbB4). Mice were housed in rooms with temperature at $23^{\circ} \mathrm{C}$ in a $12 \mathrm{~h}$ light/dark cycle and with food and water available ad libitum. Experimental procedures were approved by the Institutional Animal Care and Use Committee of Georgia Regents University. Unless otherwise indicated, 2-month-old male mice were used for all experiments. ErbB4f/f mice were used as control for Camk $2 \alpha$ $\mathrm{ErbB}^{-1-}$ and PV-ErbB4 $4^{-1-}$ mice. TRE-ErbB4 mice were used as control for ctoErbB4 mice.

Golgi staining. Golgi staining was performed by using a kit following the manufacturer's protocol (FD NeuroTechnologies). Spines were counted on secondary and tertiary branches of apical dendrites in the stratum radiatum of CA1 hippocampal region. Five $20 \mu \mathrm{m}$ segments of either secondary or tertiary dendrites were randomly selected. Spine length and width were measured by ImageJ and analyzed by investigators who were blind to genotypes.

Electron micrograph. Ultrathin sections of the CA1 region were examined with a JEM 1230 transmission electron microscope (JEOL USA) at $110 \mathrm{kV}$. Images were collected with an UltraScan 4000 CCD camera and First Light Digital Camera Controller (Gatan). Synapses were identified by ultrastructural specializations, including alignment of presynaptic and postsynaptic membranes, presynaptic and postsynaptic thickenings, and clusters of synaptic vesicles. The length and thickness of postsynaptic density (PSD) were analyzed by investigators unaware of genotypes using ImageJ.

Electrophysiology. Electrophysiology was performed as described previously (Yin et al., 2013). Briefly, slices were placed in the recording chamber that was perfused $(3 \mathrm{ml} / \mathrm{min})$ with $A C S F$ at $32-34^{\circ} \mathrm{C}$. Field EPSPs (fEPSP) were evoked in the CA1 stratum radiatum by stimulating Schaffer collaterals (SCs) with a two-concentric bipolar stimulating electrode (FHC) and recorded in current-clamp configuration by the Axon MultiClamp 700B amplifier with ACSF-filled glass pipettes (1-5 $\mathrm{M} \Omega$ ). Test stimuli consisted of monophasic $100 \mu$ s pulses of constant currents at a frequency of $0.033 \mathrm{~Hz}$. The strength of synaptic transmission was determined by measuring the initial ( $10-60 \%$ rising phase) slope of fEPSP. Whole-cell recording was aided with infrared optics using an upright microscope equipped with a $\times 40$ water-immersion lens (Olympus, BX51WI) and infrared-sensitive CCD camera. The pipette (input resistance: 4-6 $\mathrm{M} \Omega$ ) solution contained $(\mathrm{mM})$ the following: 105 K-gluconate, $30 \mathrm{KCl}, 10 \mathrm{HEPES}, 10$ phosphocreatine, 4 ATP-Mg, 0.3 GTP-Na, 0.3 EGTA, 5 QX314, pH 7.35, 285 mOsm. To measure miniature EPSCs (mEPSCs), GABA $\mathrm{A}_{\mathrm{A}}$ receptor and action potentials were blocked with $20 \mu \mathrm{M}$ bicuculline methodiode and $1 \mu \mathrm{M}$ TTX, respectively. 

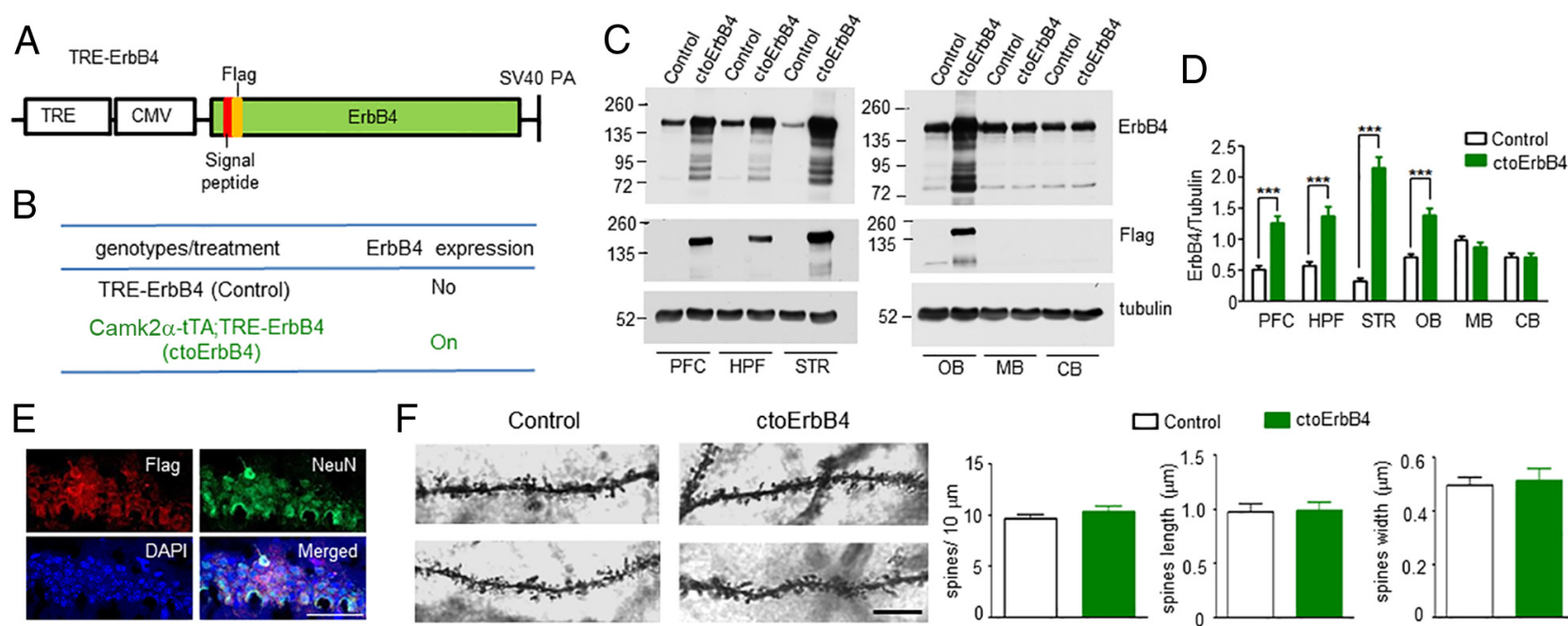

F Control
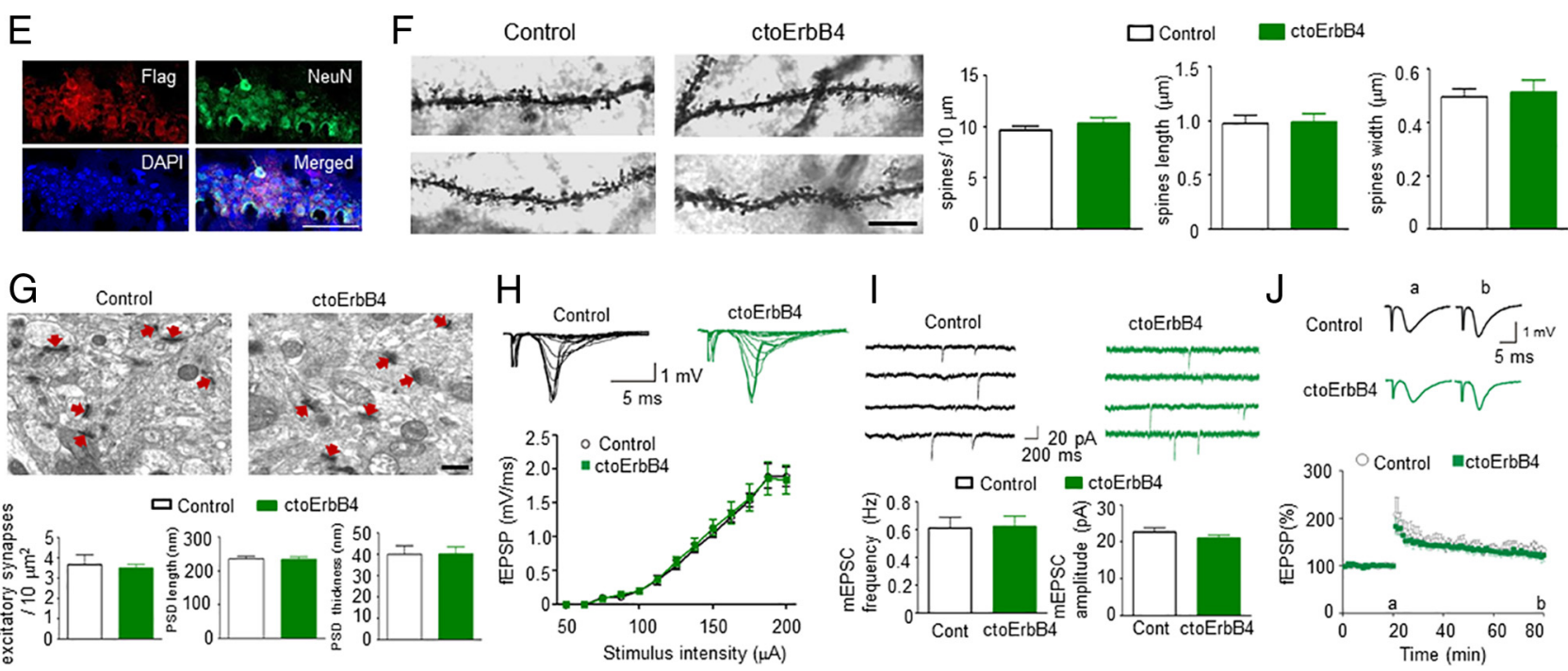

Figure 2. Overexpression of ErbB4 in pyramidal neurons did not alter spine formation and excitatory synaptic transmission in vivo. A, TRE-ErbB4 transgene structure. Full-length ErbB4 was cloned into pMM400 after the promoter complex of TRE and CMV (cytomegalus virus minimal promoter), before the SV40 polyadenylation signal. $\boldsymbol{B}$, Genotypes and ErbB4 expression. Blank and green histograms/curves represent data from control and ctoErbB4 mice, respectively. C, Expression of ErbB4 transgene in prefrontal cortex (PFC), hippocampus (HPF), striatum (STR), and olfactory bulb $(\mathrm{OB})$, but not midbrain (MB) and cerebellum (CB). Homogenates of various brain regions were subjected to Western blot analysis with indicated antibodies. $D$, Quantification of ErbB4 expression in different brain regions. Expression levels of ErbB4 were normalized by tubulin. $n=3$ per genotype. ${ }^{* * *} p<0.001$ for PFC, HPF, STR, and OB (one-way ANOVA). $\boldsymbol{E}$, Flag staining in the hippocampal CA1 region of ctoErbB4 mice. Sections were tripled-stained with anti-Flag antibody, anti-NeuN antibody, and DAPI. Scale bar, $50 \mu \mathrm{m}$. $\boldsymbol{F}$, The density, length, and width of spines were indistinguishable in the CA1 region between control and ctoErbB4 mice. Left, Representative Golgi staining images. Right, Quantification data. $n=34$ neurons from 3 mice per group. Scale bar, $10 \mu \mathrm{m}$. $\boldsymbol{G}$, Comparable numbers of excitatory synapses, PSD length, and PSD thickness in the CA1 region between control and ctoErbB4 mice. Top, Representative EM images. Bottom, Quantification data. $n=$ 105 images from 3 mice per group. Arrows indicate PSD.Scalebar, $0.5 \mu \mathrm{m}$. H,Similarl/0 curves atSC-CA1 synapses between control and ctoErbB4 mice. Top, Representative traces offEPSPs. Bottom, $/ / 0$ curves. $n=10$ slices from 4 mice per group. I, No difference in mEPSC frequency and amplitude between control and ctoErbB4 mice. Top, Representative traces. Bottom, Quantitative data. $n=9$ cells from 3 mice per group.J, Similar LTP at SC-CA1 synapses between control and ctoErbB4 mice. Top, Representative traces. Bottom, Quantification data. $n=6$ slices from 4 mice per group.

LTP was induced by theta-burst stimulation, 10 trains of 4 pulses at 100 $\mathrm{Hz}$ with an interval of $200 \mathrm{~ms}$.

Western blot. Brain tissues were homogenized in RIPA buffer containing 50 mм Tris- $\mathrm{HCl}, \mathrm{pH}$ 7.4, $150 \mathrm{~mm} \mathrm{NaCl}, 2$ mм EDTA, 1\% sodium deoxycholate, 1\% SDS, $1 \mathrm{~mm}$ PMSF, $50 \mathrm{~mm}$ sodium fluoride, $1 \mathrm{~mm}$ sodium vanadate, $1 \mathrm{~mm}$ DTT, and protease inhibitor cocktails. Homogenates were resolved on SDS-PAGE and transferred to nitrocellulose membranes, which were incubated in the TBS containing $0.1 \%$ Tween 20 and $5 \%$ milk for $1 \mathrm{~h}$ at room temperature before the addition of primary antibody for incubation overnight at $4^{\circ} \mathrm{C}$. After wash, membranes were incubated with HRP-conjugated secondary antibody in the TBS buffer for $1 \mathrm{~h}$ at room temperature. Immunoreactive bands were visualized using enhanced chemiluminescence (Pierce). Films were scanned with an Epson 1680 scanner and analyzed with ImageJ (National Institutes of Health). The following primary antibodies were used: rabbit anti-ErbB4 $(0618,1: 2000$, generously provided by Dr. Cary Lai), rabbit anti-Flag (1:1000, Sigma), and mouse anti- $\alpha$-tubulin (1:5000, Cell Signaling Technology).

Immunofluorescence. Anesthetized mice were perfused transcardially with $4 \%$ PFA in PBS, and tissues were fixed in $4 \%$ PFA at $4^{\circ} \mathrm{C}$ for $5 \mathrm{~h}$. Frozen brain blocks were cut into $40-\mu$ m-thick sections on a vibrating microtome (VT1000S; Leica Microsystem). Sections were incubated with $0.3 \%$ Triton X-100 and 5\% BSA in PBS at room temperature for $1 \mathrm{~h}$. Slices were then incubated with mouse anti-NeuN (1:1000, Millipore) or rabbit anti-Flag (1:1000, Sigma) antibodies at $4^{\circ} \mathrm{C}$ overnight. After washing with PBS for 3 times, samples were incubated with AlexaFluorconjugated secondary antibodies (1:1000, Invitrogen) for $1 \mathrm{~h}$ at room temperature. Samples were mounted with Vectashield mounting medium (Vector), and images were taken by Zeiss LSM510 confocal microscope.

Statistics analysis. Data from Golgi staining and electron microscopic analysis and mEPSCs were analyzed by Student's $t$ test. One-way ANOVA was used to analyze data from Western blot in ctoErbB4 mice. Student's $t$ test was used to analyze Western blot data from Camk $2 \alpha$ $E_{r b B 4^{-1-}}$ and PV-ErbB4 ${ }^{-1-}$ mice. Two-way ANOVA was performed for spine densities at different ages and for data of input-output (I/O) curve and paired pulse facilitation (PPF). Data were expressed as mean \pm SEM unless otherwise indicated.

\section{Results}

ErbB4 in pyramidal neurons is dispensable for spine formation

To determine whether ErbB4 in pyramidal neurons is important for spine and excitatory synapse formation, we generated excitatory neuron-specific ErbB4 mutant mice by crossing ErbB4f/f mice with Camk $2 \alpha:$ :Cre mice that express Cre in forebrain pyramidal neurons (Fig. 1A) (Tsien et al., 1996). ErbB4 levels in the 
A

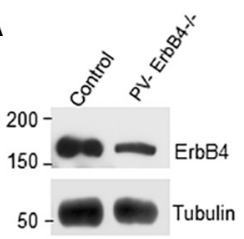

B

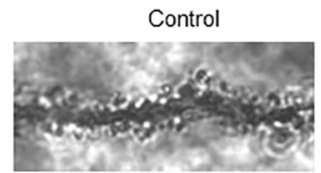

$\square$ Control

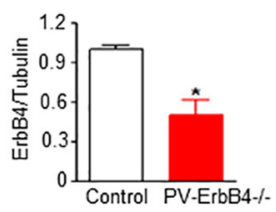

PV-ErbB4-I-

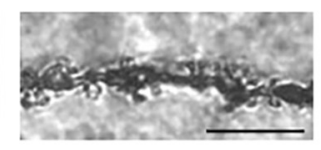

- PV-ErbB4-I.
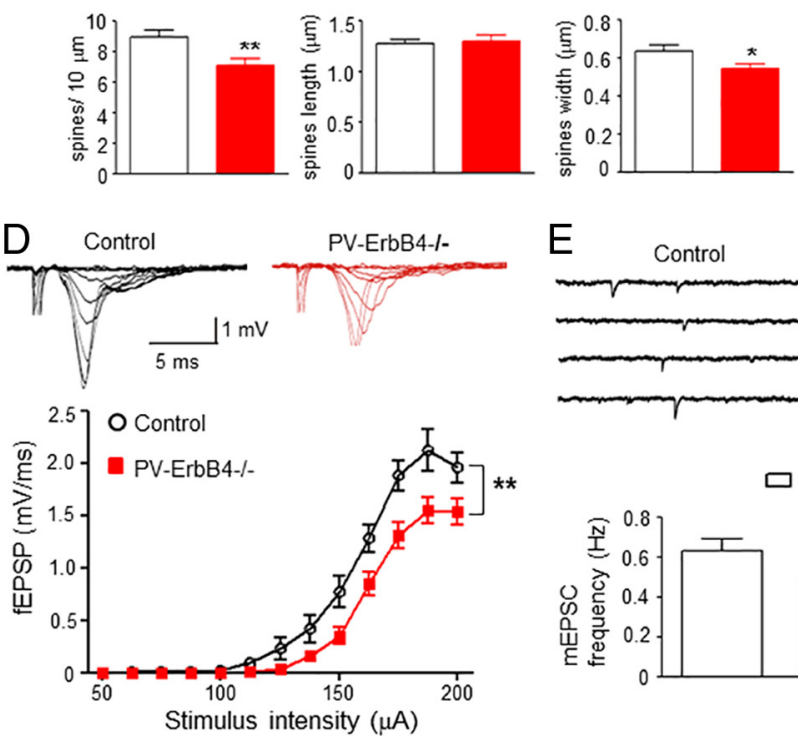

C
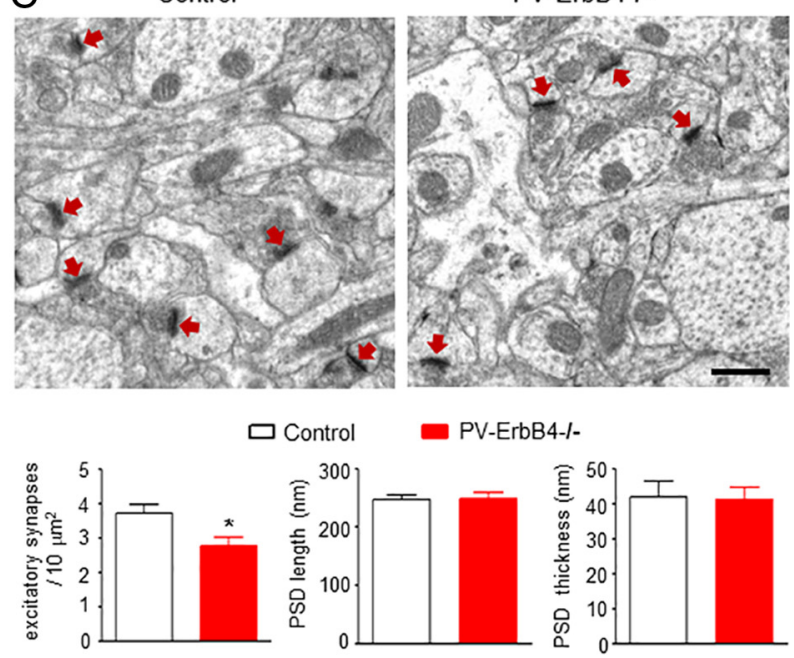

PV-ErbB4-I-

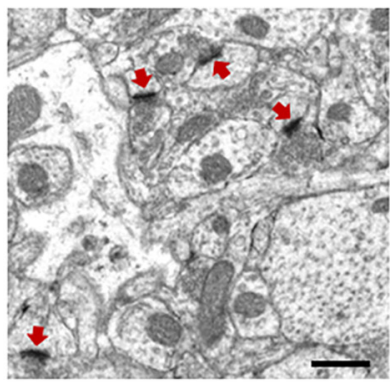

F

F control
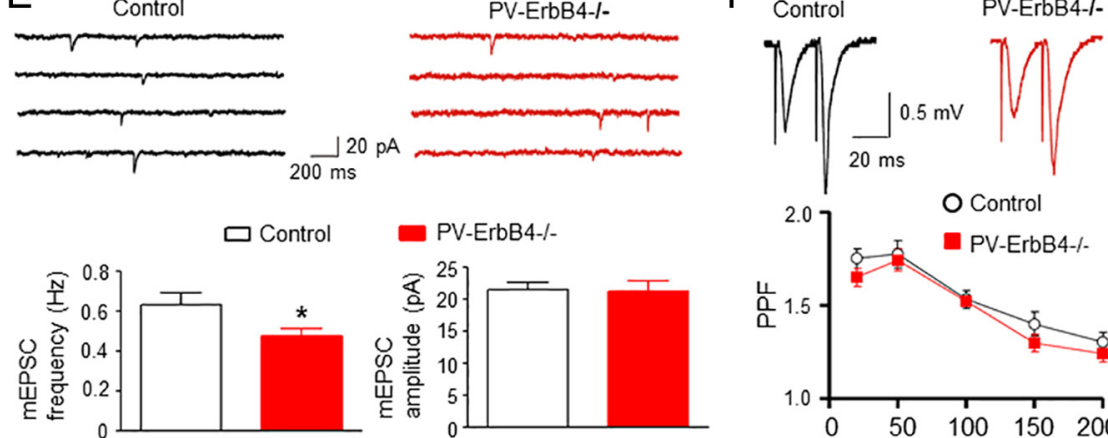

PV-ErbB4-/-
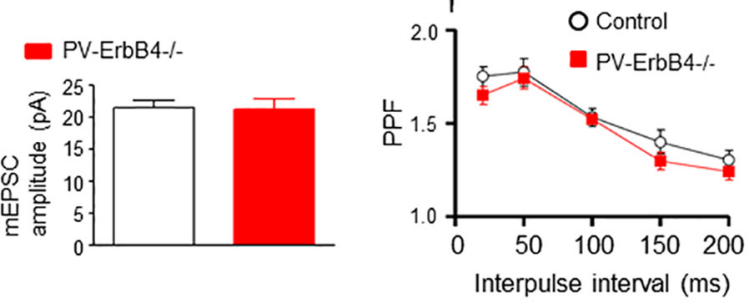

Figure 3. Deletion of ErbB4 from PV-positive neurons impairs spine formation. A, Reduction of ErbB4 protein levels in the hippocampus of PV-ErbB4 ${ }^{-1-}$ mice. Hippocampal homogenates of 2-month-old mice were subjected to Western blotting. Left, Representative blots of ErbB4 and tubulin. Right, Quantification data. Expression levels of ErbB4 were normalized by tubulin. $n=3$ mice per group. ${ }^{*} p<0.05$ ( $t$ test). $\boldsymbol{B}$, Reduced spine density and width in the CA1 region of PV-ErbB4 ${ }^{-1-}$ mice. Top, Representative Golgi staining images. Bottom, Quantitative data. $n=68$ neurons from 6 mice per group. ${ }^{* *} p<0.01$ ( $t$ test). Scale bar, $10 \mu \mathrm{m}$. C, Fewer excitatory synapses in PV-ErbB4 ${ }^{-1-}$ mice compared with control littermates. PSD length and thickness did not show significant difference between the two groups. Top, Representative EM images from CA1 regions. Bottom, Quantitative data. $n=108$ images from 3 mice per group. ${ }^{*} p<0.05$ ( $t$ test). Arrows indicate PSD. Scale bar, $0.5 \mu \mathrm{m}$. D, Impaired I/0 curves at SC-CA1 synapses in PV-ErbB4 ${ }^{-1-}$ mice. Top, Representative traces of fEPSPs. Bottom, I/0 curves. $n=14$ slices from 6 mice per group. ${ }^{* *} p<0.01$ (two-way ANOVA). $\boldsymbol{E}$, Reduced mEPSC frequency in PV-ErbB4 ${ }^{-1-}$ mice. Top, Representative mEPSC traces. Bottom, Quantitative data. $n=12$ cells from 4 mice per group. ${ }^{*} p<0.05$ ( $t$ test). $\boldsymbol{F}$, Normal PPF in PV-ErbB4 ${ }^{-1-}$ hippocampal slices. Top, Representative fEPSP traces. Bottom, Quantitative data. $n=12$ slices from 4 mice per group.

hippocampus in Camk2 $\alpha::$ Cre;ErbB4f/f mice (thereafter referred as Camk $2 \alpha-E r b B 4^{-1-}$ mice) was not changed significantly, compared with control mice (Fig. 1B) (Chen et al., 2010). This result suggests low-level (if any) of ErbB4 expression in pyramidal neurons, in agreement with previous reports (Yau et al., 2003; Vullhorst et al., 2009; Fazzari et al., 2010). Golgi staining analysis indicated that the spine density of CA1 pyramidal neurons was comparable between Camk $2 \alpha$-ErbB $4^{-1-}$ mice and control littermates (Fig. 1C). No difference was observed in spine length and width between the two genotypes (Fig. 1C). These results suggest that the number and morphology of spines may not be altered by ErbB4 deletion in CA1 pyramidal neurons. We further analyzed the number of excitatory synapses in the CA1 region by transmission electron microscopy (EM). As shown in Figure $1 D$, similar numbers of excitatory synapses were observed between Camk $2 \alpha$ $E r b B 4^{-1-}$ mice and littermate controls. The length and thickness of PSD were also similar between the two genotypes (Fig. 1D). These results indicate that ErbB4 in pyramidal neurons is not critical for the formation of spines and excitatory synapses. They extend previous findings that genetic ablation of ErbB4 from pyramidal neurons by viral expression of Cre does not alter the density or function of dendritic spines (Fazzari et al., 2010).

To determine whether ErbB4 in pyramidal neurons is important for excitatory synaptic transmission, we measured glutamate transmission at SC-CA1 synapses. The I/O curves of fEPSPs represent basal AMPA receptor-mediated currents and were comparable between Camk $2 \alpha-E r b B 4^{-1-}$ mice and control littermates (Fig. 1E). Moreover, the frequency and amplitude of mEPSCs were also similar between the two genotypes (Fig. $1 F$ ). These observations, together with the morphological results, suggest that ErbB4 in CA1 pyramidal neurons is dispensable for the structure and function of dendritic spines.

\section{Overexpression of ErbB4 in pyramidal neurons does not affect spine formation}

Next, we asked whether the increase of ErbB4 in pyramidal neurons in vivo could affect spine formation and maturation. To this end, TRE-ErbB4 mice were generated that carry the human ErbB4 (JMa, CYT2 isoform) cDNA under the control of the tetracycline-responsive promoter element (TRE) tetO (Fig. 


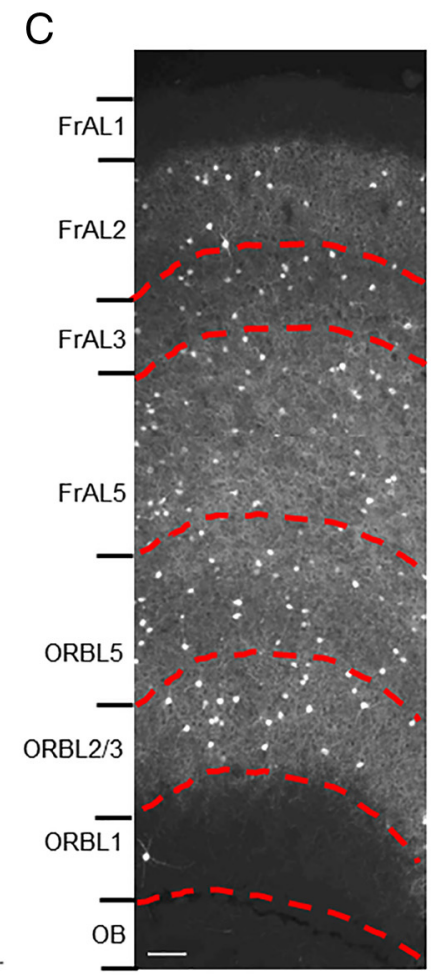

Figure 4. Reduction of spine density in FrAL3 of PV-ErbB4 ${ }^{-1-}$ mice. $\boldsymbol{A}$, Reduced spine density and width in FrAL3 of PVErbB4 ${ }^{-1-}$ mice. Top, Representative Golgi staining images of FrAL3 pyramidal neurons. Bottom, Quantitative data. $n=32$ neurons from 3 mice per group. ${ }^{* * *} p<0.001$ ( $t$ test). Scale bar, $10 \mu \mathrm{m}$. $\boldsymbol{B}$, Normal spine density and width in ORBL1 of PV-ErbB4 ${ }^{-1-}$ mice. Top, Representative Golgi staining images of ORBL1 pyramidal neurons. Bottom, Quantitative data. $n=34$ neurons from 3 mice per group. Scale bar, $10 \mu \mathrm{m}$. C, Fewer PV-positive cells in ORBL1 of the PFC. Cortical slices were stained with anti-PV antibody, which was visualized by AlexaFluor-conjugated secondary antibodies. OB, Olfactory bulb. Scale bar, $100 \mu \mathrm{m}$.

$2 A)$. A Flag tag was inserted immediately after the artificial signal peptide of ErbB4 cDNA, which did not interfere with ErbB4 processing and function (Huang et al., 2000). TRE-ErbB4 mice did not express ErbB4 in the absence of tetracycline transactivator (tTA) (Fig. 2 B, C). To overexpress ErbB4 specifically in pyramidal neurons, TRE-ErbB4 mice were crossed with Camk2 $\alpha:$ :tTA mice that express tTA in excitatory neurons (Mayford et al., 1996). Resulting bitransgenic Camk $2 \alpha:: t T A ; T R E-E r b B 4$ mice (named as ctoErbB4 mice for Camk $2 \alpha$ promoter-driven tet-off ErbB4) produced Flag-ErbB4 in excitatory neurons (Fig. 2C-E). Compared with TRE-ErbB4 or control mice, ErbB4 was increased by onefold to twofold in the prefrontal cortex (PFC) and hippocampus in ctoErbB4 mice (Fig. 2C,D). The increase was the result of expression of the transgene, which was detectable by an anti-Flag antibody (Fig. 2C,E). Moreover, the increase was forebrain-specific, and not detectable in the midbrain and cerebellum (Fig. 2C,D), in agreement with the expression of Camk $2 \alpha$ tTA (Mayford et al., 1996). Together, these results indicate that ctoErbB4 mice express higher levels of ErbB4 in pyramidal neurons in forebrain regions, including hippocampus.

As shown in Figure $2 F$, the density, length, and width of spines in CA1 pyramidal neurons were comparable between ctoErbB4 mice and control littermates, suggesting that overexpression of ErbB4 in pyramidal neurons does not alter the number or size of dendritic spines. To further test this hypothesis, we performed two additional experiments. First, we examined excitatory synapses in the CA1 region by EM. The number of excitatory synapses and the PSD length and thickness were indistinguishable between ctoErbB4 mice and control littermates (Fig. 2G), in agreement with studies from Golgi staining. Second, we charac- terized glutamate transmission at $\mathrm{SC}-$ CA1 synapses. As shown in Figure $2 \mathrm{H}, \mathrm{I} / \mathrm{O}$ curves of fEPSPs were similar between ctoErbB4 mice and control littermates, suggesting that in vivo overexpression of ErbB4 in pyramidal neurons did not alter basal glutamatergic transmission. In agreement, the frequency and amplitude of mEPSCs were also comparable between the two genotypes (Fig. 2I). Moreover, LTP at SC-CA1 synapses was similar between ctoErbB4 and control hippocampal slices (Fig. 2J). These findings were consistent with previous reports that ErbB4 in pyramidal neurons is not crucial for NRG1 to suppress LTP (Chen et al., 2010; Shamir et al., 2012). Together, these observations indicate that increased ErbB4 levels in excitatory neurons do not alter the number, structure, or function of excitatory synapses in pyramidal neurons.

\section{ErbB4 deletion in PV-positive GABAergic interneurons impairs spine formation}

Spine density in hippocampal pyramidal neurons was reduced by ErbB4 deletion in all neural cells (Barros et al., 2009). We demonstrate that ErbB4 ablation or overexpression in excitatory neurons has little effect on the number and function of excitatory synapses in the hippocampus (Figs. 1 and 2). These observations suggest that ErbB4 in nonexcitatory neurons may regulate spine formation or function. Given that ErbB4 is highly expressed in PVpositive GABAergic interneurons (Yau et al., 2003; Vullhorst et al., 2009; Fazzari et al., 2010), we speculated that spine impairment may be mediated by ErbB4 deficiency in PV-positive neurons. To test this hypothesis, we crossed ErbB4f/f mice with $\mathrm{PV}::$ Cre mice to get the PV::Cre;ErbB4f/f mice (referred to as $\mathrm{PV}-E r b B 4^{-/-}$mice thereafter). Unless otherwise indicated, mice at 2 months of age were characterized for ErbB4 expression, spine morphology, and electrophysiology. ErbB4 was specifically deleted from PV-positive neurons in PV-ErbB4 ${ }^{-1-}$ mice (Chen et al., 2010; Wen et al., 2010; Shamir et al., 2012). As shown in Figure $3 A$, ErbB4 protein in hippocampus was significantly decreased in PV-ErbB4 $4^{-1-}$ mice compared with control mice, suggesting that ErbB4 is largely restricted into GABAergic interneurons (Yau et al., 2003; Vullhorst et al., 2009; Fazzari et al., 2010). Intriguingly, spine density and width of CA1 pyramidal neurons were reduced in PV-ErbB $4^{-1-}$ mice compared with control littermates (Fig. 3B). EM analysis demonstrated fewer excitatory synapses in hippocampal CA1 region in PV-ErbB4 ${ }^{-/-}$ mice than control littermates (Fig. 3C).

In accordance with the structural changes, I/O curves of fEPSPs were shifted downward in PV-ErbB4 ${ }^{-1-}$ hippocampal slices compared with control littermates (Fig. 3D), suggesting impaired basal glutamatergic transmission at SC-CA1 synapses. In addition, the frequency, but not the amplitude, of mEPSCs was reduced in PV-ErbB4 ${ }^{-/-}$mice compared with their control littermates (Fig. $3 E$ ). To determine whether decreased mEPSC frequency results from reduced number of functional synapses or impaired glutamate release, we measured fEPSPs evoked by two 

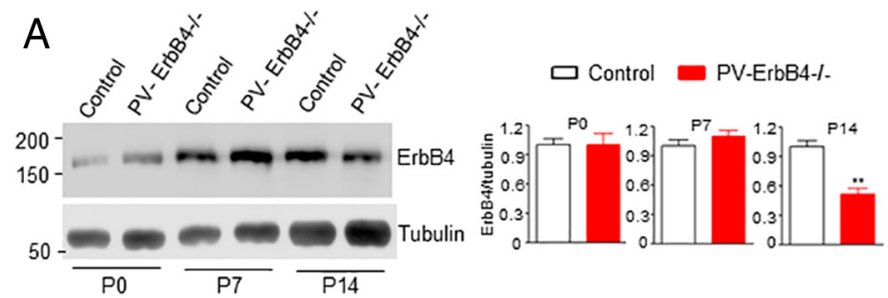

C
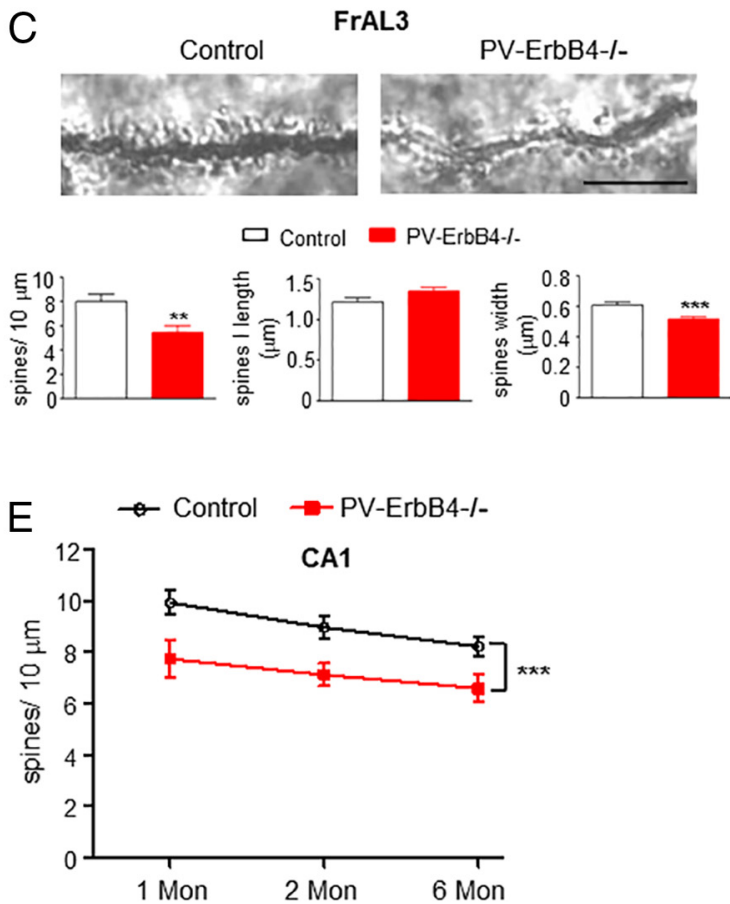
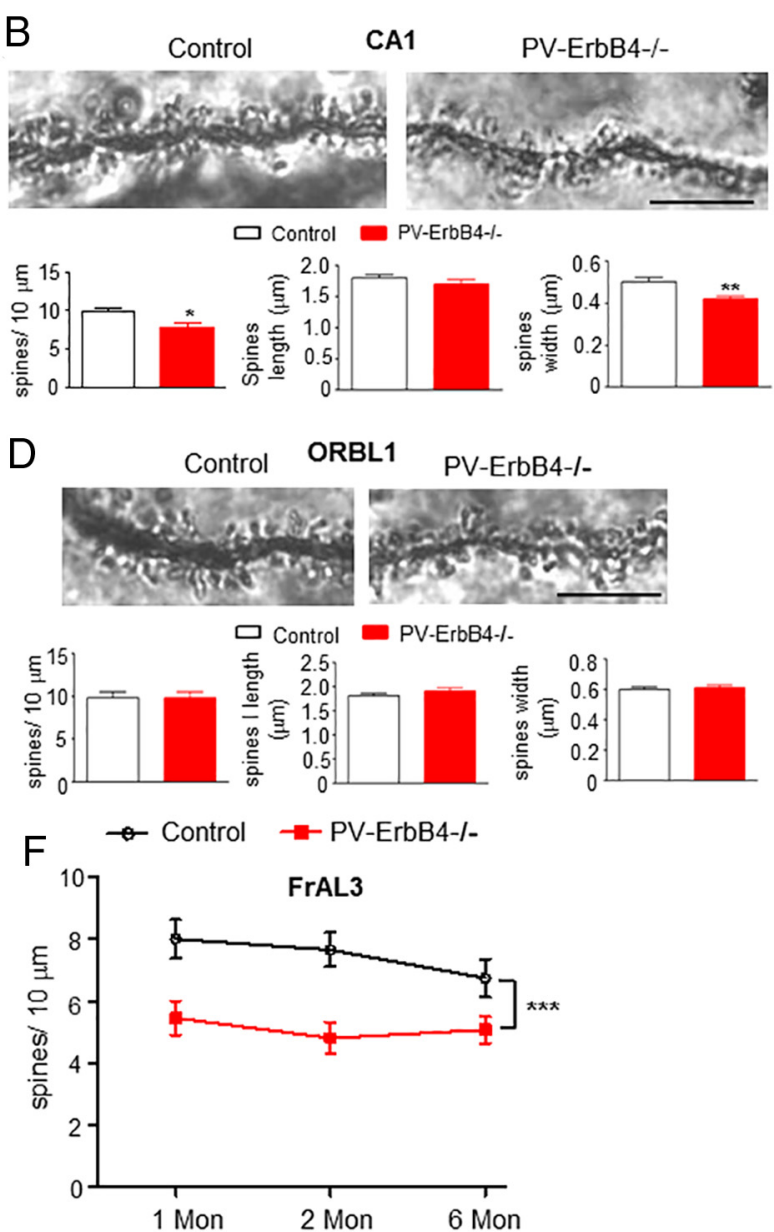

Figure 5. Impaired spine formation, but not degeneration, in PV-ErbB4 ${ }^{-1-}$ mice. $A$, ErbB4 was decreased in PV-ErbB4 ${ }^{-1-}$ hippocampus at P14. Left, Representative blots of ErbB4 and tubulin from P0, P7, or P14 control and PV-ErbB4 ${ }^{-1-}$ mice. Right, Quantification data. Expression levels of ErbB4 were normalized by tubulin. $n=3$ mice per group. ${ }^{* *} p<0.01$ ( $t$ test). $\boldsymbol{B}$, Reduced spine density and width in the CA1 region of 1-month-old PV-ErbB4 ${ }^{-1-}$ mice. Top, Representative Golgi staining images of CA1 pyramidal neurons. Bottom, Quantitative data. $n=30$ neurons from 3 mice per group. ${ }^{* *} p<0.01$ ( $t$ test). ${ }^{*} p<0.05$ (t test). Scale bar, $10 \mu \mathrm{m}$. C, Reduced spine density and width in FrAL3 of 1-month-old PV-ErbB4 ${ }^{-/-}$mice. Top, Representative Golgi staining images of FrAL3 pyramidal neurons. Bottom, Quantitative data. $n=33$ neurons from 3 mice per group. ${ }^{* *} p<0.001$ ( $t$ test). ${ }^{* *} p<0.01$ ( $t$ test). Scale bar, $10 \mu$ m. $D$, Normal spine density and width in ORBL1 of 1-month-old PV-ErbB4 ${ }^{-1-}$ mice. Top, Representative Golgi staining images of ORBL1 pyramidal neurons. Bottom, Quantitative data. $n=32$ neurons from 3 mice per group. Scale bar, $10 \mu \mathrm{m} . \boldsymbol{E}$, Spine density in the (A1 region of PV-ErbB4 ${ }^{-1-}$ and control mice at different ages. ${ }^{* * *} p<0.001$ (two-way ANOVA). $\boldsymbol{F}$, Spine density in FrAL3 of PV-ErbB4 ${ }^{-I-}$ and control mice at different ages. ${ }^{* *} p<0.001$ (two-way ANOVA).

presynaptic stimulations delivered at different intervals (i.e., paired pulses). The PPF of initial slopes of fEPSPs was comparable between PV-ErbB4 ${ }^{-1-}$ and control slices (Fig. 3F), indicating no alteration of glutamate release. These results suggest that reduced mEPSC frequency in PV-ErbB4 ${ }^{-1-}$ mice is likely the result of less excitatory synapses. Together, these results demonstrate that ErbB4 in PV-positive interneurons plays a critical role in regulating excitatory synapse formation in pyramidal neurons.

\section{Reduced spine density in PFC layer 3 in PV-ErbB4 ${ }^{-1-}$ mice}

$\mathrm{PFC}$ is increasingly implicated in schizophrenia. In particular, spine density reduction was observed in the PFC of patients with schizophrenia (Glantz and Lewis, 2000). Having demonstrated a role of ErbB4 in regulating spine density in the hippocampus, we next determined whether spine formation in the PFC is regulated by similar mechanisms. To this end, we analyzed dendritic spines in neurons in superficial and deep layers of PFC. As shown in Figure $4 A$, spine density and width, revealed by Golgi staining, were reduced in the frontal association area layer 3 (FrAL3) of PFC in PV-ErbB4 ${ }^{-1-}$ mice, compared with control littermates. However, spine density and width in orbital area layer 1 (ORBL1) appeared not altered by ErbB4 deletion in PV-positive neurons (Fig. 4B). This regional difference of ErbB4 ablation effect on spines may be the result of fewer PV-positive neurons in ORBL1, compared with FrAL3 (Fig. 4C).

Reduction of spine density in adolescent $\mathrm{PV}-E r b B 4^{-/-}$mice To determine whether spine density reduction in 2-month-old PV-ErbB4 ${ }^{-1-}$ mice was the result of developmental deficit or degeneration, we determined when the ErbB4 protein was decreased in PV-ErbB4 $4^{-1-}$ mice. As shown in Figure 5A, ErbB4 reduction was not apparent in early postnatal days (P0 and P7); however, significant reduction was observed in the hippocampus in P14 PV-ErbB4 ${ }^{-1-}$ mice. This time course was consistent with that of PV promoter activity during development (del Río et al., 1994). Given that spine formation peaks in postnatal weeks 3-5 (Boyer et al., 1998), we next determined whether spine density was reduced during this stage in PV-ErbB4 $4^{-1-}$ mice. Golgi staining was performed to analyze neurons in hippocampus and PFC from 1-month-old mice. Intriguingly, the reduction in spine density and width was observed in the PV-ErbB4 ${ }^{-1-}$ CA1 region and FrAL3 in 1 month of age, compared with control littermates 
(Fig. $5 B, C$ ). In contrast, the reduction of spine density and width did not occur in the ORBL1 from 1-month-old PV-ErbB4 ${ }^{-1-}$ mice (Fig. 5D), in agreement with the results from 2-month-old PV-ErbB4 $4^{-1-}$ mice (Fig. $4 B$ ). To address whether the spine reduction in PV-ErbB4 ${ }^{-1-}$ mice evolves with aging, we analyzed dendritic spines in 6-month-old PV-ErbB4 ${ }^{-1-}$ mice and control littermates. Spine reduction in PV-ErbB4 $4^{-1-}$ mice did not worsen with aging, compared with control littermates (Fig. $5 E, F)$. These results demonstrate that the reduction of spine density in PV-ErbB4 ${ }^{-1-}$ mice may result from impaired spine formation, not neuronal degeneration.

\section{Discussion}

ErbB4 has been implicated in the formation of excitatory synapses in the hippocampus and cortex. Conditional ablation of ErbB2 and ErbB4 (generated by hGFAP::Cre) reduces dendritic spine density in hippocampal and cortical neurons in single- and double-mutant mice (Barros et al., 2009). The cellular mechanisms by which ErbB4 regulates spine formation remain unclear. ErbB4 knockdown from pyramidal neurons reduces spine density and size in organotypical hippocampal slices, suggesting that ErbB4 may be necessary for spine formation (Li et al., 2007). On the other, ablation of ErbB4 in pyramidal neurons of floxedErbB4 mice (using retroviral Cre expression) did not alter the density of dendritic spines or mEPSC (Fazzari et al., 2010). In light of accumulating evidence that ErbB4 expression is high or specific in GABAergic interneurons and low or absent in pyramidal neurons (Huang et al., 2000; Yau et al., 2003; Vullhorst et al., 2009; Fazzari et al., 2010), we mutated the ErbB4 gene specifically in PV-positive cells, a major type of interneurons that express ErbB4 (Vullhorst et al., 2009; Fazzari et al., 2010), and pyramidal neurons and determined the in vivo effect of ErbB4 mutation on spine development. We found that ablation of the $\operatorname{ErbB} 4$ gene (by Camk $2 \alpha:$ :Cre) from pyramidal neurons did not affect spine density or function in the hippocampus and cortex. In contrast, the spine density was reduced in PV-ErbB4 ${ }^{-1-}$ mice where ErbB4 was selectively deleted from PV-positive GABAergic interneurons. These observations indicate that ErbB4 in PV-positive neurons promotes spine formation during development. In support of our hypothesis is a recent finding that demonstrated a noncell-autonomous role for ErbB4 in spine formation (Del Pino et al., 2013).

Because hGFAP::Cre expresses in neural precursors starting at E13.5 (Zhuo et al., 2001), a parsimonious model is that spine deficits in the conditional ErbB2/ErbB4 double-mutant mice (Barros et al., 2009) are the result of defects in nonpyramidal cells. Loss of ErbB4 in interneurons compromises GABAergic transmission (Woo et al., 2007; Chen et al., 2010; Wen et al., 2010). During early development, GABA depolarizes immature neurons resulting from high intracellular $\mathrm{Cl}^{-}$concentration (Ben-Ari, 2002; Owens and Kriegstein, 2002). GABA-mediated depolarization is critical in the formation of spines and excitatory synapses (Ben-Ari et al., 1997; Akerman and Cline, 2006; Ge et al., 2006; Wang and Kriegstein, 2008). Thus, in ErbB4 mutant mice, impaired GABA release from interneurons during early development might lead to fewer spines and excitatory synapses. In support of this hypothesis was the observation that ErbB4 protein is reduced in PV-ErbB4 $4^{-/-}$mice at postnatal day 14, before the peak of spine formation (Boyer et al., 1998).

Alternatively and perhaps in addition, deletion of ErbB4 from fast-spiking interneurons (which are PV-positive) impairs the assembly and function of the GABAergic circuitry (Fazzari et al., 2010; Ting et al., 2011; Del Pino et al., 2013). Compromised
GABA transmission in ErbB4 mutant mice increases the activity of pyramidal neurons (Wen et al., 2010; Del Pino et al., 2013), which may lead to a compensatory reduction in spine formation. Consistent with this notion, in PV-ErbB4 $4^{-1-}$ mice, spine reduction was observed in hippocampal CA1 and FrAL3 of the PFC, where PV-positive cells were abundant, but not in ORBL1 of the PFC, where few PV-positive cells were present (Fig. 4). Moreover, ErbB4 in PV-positive GABAergic interneurons, but not in pyramidal neurons, is crucial for NRG1 regulation of synaptic plasticity, such as LTP (Chen et al., 2010; Shamir et al., 2012). Together, these studies provide strong evidence that ErbB4 in GABAergic interneurons plays a role in the development and function of cortical and hippocampal excitatory synapses.

Acute overexpression of ErbB4 in pyramidal neurons was shown to increase spine size but not density in organotypical hippocampal slices (Li et al., 2007). In ctoErbB4 mice, the spine size and excitatory synaptic transmission in the hippocampus were similar to those of control mice (Fig. 2), suggesting that increasing ErbB4 expression in pyramidal neurons is not able to alter spines in vivo. We notice the difference of levels and duration of ErbB4 expression between the two studies. ErbB4 expression by transient in vitro transfection might be higher than that in ctoErbB4 mice. Spines were analyzed in 2-month-old ctoErbB4 mice when synapses are pretty mature, whereas spines may be immature in DIV 6-9 hippocampal slices (2-3 d after transfection) (Li et al., 2007). Homeostatic mechanisms may have reduced the effect of ErbB4 overexpression in ctoErbB4 mice.

The spine density is reduced in the PFC and hippocampus of schizophrenia patients (Garey et al., 1998; Glantz and Lewis, 2000; Kolomeets et al., 2005), which may contribute to impaired glutamatergic transmission in schizophrenia (Lewis and Sweet, 2009; Yin et al., 2012). Interestingly, spine reduction is more dramatic in layer 3 PFC than in other brain regions in patients with schizophrenia (Glantz and Lewis, 2000) and in PVErbB4 $4^{-1-}$ mice (Fig. 4). Reduced NRG1 protein levels and ErbB4 truncation mutants have been reported in patients with schizophrenia (Bertram et al., 2007; Walsh et al., 2008; Parlapani et al., 2010). Thus, compromised spine density may serve as a pathophysiological mechanism of schizophrenia related with NRG1 and ErbB4.

Although the majority of spines are localized on dendrites of pyramidal neurons, spines are detectable on dendrites of some PV-negative GABAergic interneurons, including somatostatinand calbindin-positive cells (Guirado et al., 2013). ErbB4 expression appears to be low in somatostatin- and calbindin-positive GABAergic interneurons in hippocampus (Neddens and Buonanno, 2010). However, some somatostatin-positive cells in cerebral cortex express ErbB4 (Yau et al., 2003). Given that ErbB4 is enriched in postsynaptic fraction and interacts with PSD95 (Garcia et al., 2000; Huang et al., 2000), it would be interesting to determine whether ErbB4 may also regulate the spine formation in somatostatin-positive cells in cerebral cortex.

\section{References}

Akerman CJ, Cline HT (2006) Depolarizing GABAergic conductances regulate the balance of excitation to inhibition in the developing retinotectal circuit in vivo. J Neurosci 26:5117-5130. CrossRef Medline

Barros CS, Calabrese B, Chamero P, Roberts AJ, Korzus E, Lloyd K, Stowers L, Mayford M, Halpain S, Müller U (2009) Impaired maturation of dendritic spines without disorganization of cortical cell layers in mice lacking NRG1/ErbB signaling in the central nervous system. Proc Natl Acad Sci U S A 106:4507-4512. CrossRef Medline

Ben-Ari Y (2002) Excitatory actions of GABA during development: the nature of the nurture. Nat Rev Neurosci 3:728-739. CrossRef Medline 
Ben-Ari Y, Khazipov R, Leinekugel X, Caillard O, Gaiarsa JL (1997) GABAA, NMDA and AMPA receptors: a developmentally regulated 'menage a trios.' Trends Neurosci 20:523-529. CrossRef Medline

Bertram I, Bernstein HG, Lendeckel U, Bukowska A, Dobrowolny H, Keilhoff G, Kanakis D, Mawrin C, Bielau H, Falkai P, Bogerts B (2007) Immunohistochemical evidence for impaired neuregulin-1 signaling in the prefrontal cortex in schizophrenia and in unipolar depression. Ann N Y Acad Sci 1096:147-156. CrossRef Medline

Boyer C, Schikorski T, Stevens CF (1998) Comparison of hippocampal dendritic spines in culture and in brain. J Neurosci 18:5294-5300. Medline

Chen YJ, Zhang M, Yin DM, Wen L, Ting A, Wang P, Lu YS, Zhu XH, Li SJ, Wu CY, Wang XM, Lai C, Xiong WC, Mei L, Gao TM (2010) ErbB4 in parvalbumin-positive interneurons is critical for neuregulin 1 regulation of long-term potentiation. Proc Natl Acad Sci U S A 107:21818-21823. CrossRef Medline

Del Pino I, García-Frigola C, Dehorter N, Brotons-Mas JR, Alvarez-Salvado E, Martínez de Lagrán M, Ciceri G, Gabaldón MV, Moratal D, Dierssen M, Canals S, Marín O, Rico B (2013) Erbb4 deletion from fast-spiking interneurons causes schizophrenia-like phenotypes. Neuron 79:11521168. CrossRef Medline

del Río JA, de Lecea L, Ferrer I, Soriano E (1994) The development of parvalbumin-immunoreactivity in the neocortex of the mouse. Brain Res Dev Brain Res 81:247-259. CrossRef Medline

Fazzari P, Paternain AV, Valiente M, Pla R, Luján R, Lloyd K, Lerma J, Marín O, Rico B (2010) Control of cortical GABA circuitry development by Nrg1 and ErbB4 signalling. Nature 464:1376-1380. CrossRef Medline

Flames N, Long JE, Garratt AN, Fischer TM, Gassmann M, Birchmeier C, Lai C, Rubenstein JL, Marín O (2004) Short- and long-range attraction of cortical GABAergic interneurons by neuregulin-1. Neuron 44:251-261. CrossRef Medline

Garcia RA, Vasudevan K, Buonanno A (2000) The neuregulin receptor ErbB-4 interacts with PDZ-containing proteins at neuronal synapses. Proc Natl Acad Sci U S A 97:3596-3601. CrossRef Medline

Garey LJ, Ong WY, Patel TS, Kanani M, Davis A, Mortimer AM, Barnes TR, Hirsch SR (1998) Reduced dendritic spine density on cerebral cortical pyramidal neurons in schizophrenia. J Neurol Neurosurg Psychiatry 65: 446-453. CrossRef Medline

Ge S, Goh EL, Sailor KA, Kitabatake Y, Ming GL, Song H (2006) GABA regulates synaptic integration of newly generated neurons in the adult brain. Nature 439:589-593. CrossRef Medline

Glantz LA, Lewis DA (2000) Decreased dendritic spine density on prefrontal cortical pyramidal neurons in schizophrenia. Arch Gen Psychiatry 57:65-73. CrossRef Medline

Glausier JR, Lewis DA (2013) Dendritic spine pathology in schizophrenia. Neuroscience 251:90-107. CrossRef Medline

Gray EG (1959) Electron microscopy of synaptic contacts on dendrite spines of the cerebral cortex. Nature 183:1592-1593. CrossRef Medline

Guirado R, Perez-Rando M, Sanchez-Matarredona D, Castillo-Gomez E, Liberia T, Rovira-Esteban L, Varea E, Crespo C, Blasco-Ibanez JM, Nacher J (2013) The dendritic spines of interneurons are dynamic structures influenced by PSA-NCAM expression. Cereb Cortex. Advance online publication. Retrieved June 17, 2013. doi: 10.1093/cercor/bht156. CrossRef Medline

Harris KM, Kater SB (1994) Dendritic spines: cellular specializations imparting both stability and flexibility to synaptic function. Annu Rev Neurosci 17:341-371. CrossRef Medline

Huang YZ, Won S, Ali DW, Wang Q, Tanowitz M, Du QS, Pelkey KA, Yang DJ, Xiong WC, Salter MW, Mei L (2000) Regulation of neuregulin signaling by PSD-95 interacting with ErbB4 at CNS synapses. Neuron 26: 443-455. CrossRef Medline

Kolomeets NS, Orlovskaya DD, Rachmanova VI, Uranova NA (2005) Ultrastructural alterations in hippocampal mossy fiber synapses in schizophrenia: a postmortem morphometric study. Synapse 57:47-55. CrossRef Medline

Lewis DA, Levitt P (2002) Schizophrenia as a disorder of neurodevelopment. Annu Rev Neurosci 25:409-432. CrossRef Medline

Lewis DA, Sweet RA (2009) Schizophrenia from a neural circuitry perspective: advancing toward rational pharmacological therapies. J Clin Invest 119:706-716. CrossRef Medline

Li B, Woo RS, Mei L, Malinow R (2007) The neuregulin-1 receptor erbB4 controls glutamatergic synapse maturation and plasticity. Neuron 54: 583-597. CrossRef Medline
Madisen L, Zwingman TA, Sunkin SM, Oh SW, Zariwala HA, Gu H, Ng LL, Palmiter RD, Hawrylycz MJ, Jones AR, Lein ES, Zeng H (2010) A robust and high-throughput Cre reporting and characterization system for the whole mouse brain. Nat Neurosci 13:133-140. CrossRef Medline

Mayford M, Bach ME, Huang YY, Wang L, Hawkins RD, Kandel ER (1996) Control of memory formation through regulated expression of a CaMKII transgene. Science 274:1678-1683. CrossRef Medline

Mei L, Xiong WC (2008) Neuregulin 1 in neural development, synaptic plasticity and schizophrenia. Nat Rev Neurosci 9:437-452. CrossRef Medline

Neddens J, Buonanno A (2010) Selective populations of hippocampal interneurons express ErbB4 and their number and distribution is altered in ErbB4 knockout mice. Hippocampus 20:724-744. CrossRef Medline

Owens DF, Kriegstein AR (2002) Is there more to GABA than synaptic inhibition? Nat Rev Neurosci 3:715-727. CrossRef Medline

Parlapani E, Schmitt A, Wirths O, Bauer M, Sommer C, Rueb U, Skowronek MH, Treutlein J, Petroianu GA, Rietschel M, Falkai P (2010) Gene expression of neuregulin-1 isoforms in different brain regions of elderly schizophrenia patients. World J Biol Psychiatry 11:243-250. CrossRef Medline

Penzes P, Cahill ME, Jones KA, VanLeeuwen JE, Woolfrey KM (2011) Dendritic spine pathology in neuropsychiatric disorders. Nat Neurosci 14: 285-293. CrossRef Medline

Pitcher GM, Beggs S, Woo RS, Mei L, Salter MW (2008) ErbB4 is a suppressor of long-term potentiation in the adult hippocampus. Neuroreport 19:139-143. CrossRef Medline

Shamir A, Kwon OB, Karavanova I, Vullhorst D, Leiva-Salcedo E, Janssen MJ, Buonanno A (2012) The importance of the NRG-1/ErbB4 pathway for synaptic plasticity and behaviors associated with psychiatric disorders. J Neurosci 32:2988-2997. CrossRef Medline

Shi J, Levinson DF, Duan J, Sanders AR, Zheng Y, Pe'er I, Dudbridge F, Holmans PA, Whittemore AS, Mowry BJ, Olincy A, Amin F, Cloninger CR, Silverman JM, Buccola NG, Byerley WF, Black DW, Crowe RR, Oksenberg JR, Mirel DB, et al. (2009) Common variants on chromosome 6p22.1 are associated with schizophrenia. Nature 460:753-757. CrossRef Medline

Silberberg G, Darvasi A, Pinkas-Kramarski R, Navon R (2006) The involvement of ErbB4 with schizophrenia: association and expression studies. Am J Med Genet B Neuropsychiatr Genet 141B:142-148. CrossRef Medline

Stefansson H, Sigurdsson E, Steinthorsdottir V, Bjornsdottir S, Sigmundsson T, Ghosh S, Brynjolfsson J, Gunnarsdottir S, Ivarsson O, Chou TT, Hjaltason O, Birgisdottir B, Jonsson H, Gudnadottir VG, Gudmundsdottir E, Bjornsson A, Ingvarsson B, Ingason A, Sigfusson S, Hardardottir H, et al. (2002) Neuregulin 1 and susceptibility to schizophrenia. Am J Hum Genet 71:877-892. CrossRef Medline

Sullivan PF, Lin D, Tzeng JY, van den Oord E, Perkins D, Stroup TS, Wagner M, Lee S, Wright FA, Zou F, Liu W, Downing AM, Lieberman J, Close SL (2008) Genomewide association for schizophrenia in the CATIE study: results of stage 1. Mol Psychiatry 13:570-584. CrossRef Medline

Ting AK, Chen Y, Wen L, Yin DM, Shen C, Tao Y, Liu X, Xiong WC, Mei L (2011) Neuregulin 1 promotes excitatory synapse development and function in GABAergic interneurons. J Neurosci 31:15-25. CrossRef Medline

Tsien JZ, Chen DF, Gerber D, Tom C, Mercer EH, Anderson DJ, Mayford M, Kandel ER, Tonegawa S (1996) Subregion- and cell type-restricted gene knockout in mouse brain. Cell 87:1317-1326. CrossRef Medline

Vullhorst D, Neddens J, Karavanova I, Tricoire L, Petralia RS, McBain CJ, Buonanno A (2009) Selective expression of ErbB4 in interneurons, but not pyramidal cells, of the rodent hippocampus. J Neurosci 29:1225512264. CrossRef Medline

Walsh T, McClellan JM, McCarthy SE, Addington AM, Pierce SB, Cooper GM, Nord AS, Kusenda M, Malhotra D, Bhandari A, Stray SM, Rippey CF, Roccanova P, Makarov V, Lakshmi B, Findling RL, Sikich L, Stromberg T, Merriman B, Gogtay N, et al. (2008) Rare structural variants disrupt multiple genes in neurodevelopmental pathways in schizophrenia. Science 320:539-543. CrossRef Medline

Wang DD, Kriegstein AR (2008) GABA regulates excitatory synapse formation in the neocortex via NMDA receptor activation. J Neurosci 28:55475558. CrossRef Medline

Weinberger DR (1987) Implications of normal brain development for the 
pathogenesis of schizophrenia. Arch Gen Psychiatry 44:660-669. CrossRef Medline

Wen L, Lu YS, Zhu XH, Li XM, Woo RS, Chen YJ, Yin DM, Lai C, Terry AV Jr, Vazdarjanova A, Xiong WC, Mei L (2010) Neuregulin 1 regulates pyramidal neuron activity via ErbB4 in parvalbumin-positive interneurons. Proc Natl Acad Sci U S A 107:1211-1216. CrossRef Medline

Woo RS, Li XM, Tao Y, Carpenter-Hyland E, Huang YZ, Weber J, Neiswender H, Dong XP, Wu J, Gassmann M, Lai C, Xiong WC, Gao TM, Mei L (2007) Neuregulin-1 enhances depolarization-induced GABA release. Neuron 54:599-610. CrossRef Medline

Yang JZ, Si TM, Ruan Y, Ling YS, Han YH, Wang XL, Zhou M, Zhang HY, Kong QM, Liu C, Zhang DR, Yu YQ, Liu SZ, Ju GZ, Shu L, Ma DL, Zhang D (2003) Association study of neuregulin 1 gene with schizophrenia. Mol Psychiatry 8:706-709. CrossRef Medline
Yau HJ, Wang HF, Lai C, Liu FC (2003) Neural development of the neuregulin receptor ErbB4 in the cerebral cortex and the hippocampus: preferential expression by interneurons tangentially migrating from the ganglionic eminences. Cereb Cortex 13:252-264. CrossRef Medline

Yin DM, Chen YJ, Sathyamurthy A, Xiong WC, Mei L (2012) Synaptic dysfunction in schizophrenia. Adv Exp Med Biol 970:493-516. CrossRef Medline

Yin DM, Chen YJ, Lu YS, Bean JC, Sathyamurthy A, Shen C, Liu X, Lin TW, Smith CA, Xiong WC, Mei L (2013) Reversal of behavioral deficits and synaptic dysfunction in mice overexpressing neuregulin 1 . Neuron 78 : 644-657. CrossRef Medline

Zhuo L, Theis M, Alvarez-Maya I, Brenner M, Willecke K, Messing A (2001) hGFAP-cre transgenic mice for manipulation of glial and neuronal function in vivo. Genesis 31:85-94. CrossRef Medline 